\title{
THE ANALYSIS OF FIRM FINANCIAL PERFORMANCE INFLUENCE TOWARDS ECO-INNOVATION ON INDONESIAN CONSUMER GOODS COMPANIES
}

\author{
Diah Permata Sari ${ }^{1}$; Retno Kusumastuti ${ }^{2}$ \\ 1Faculty of Administrative Sciences, Universitas Indonesia, Indonesia \\ 2PWCoopers Jakarta, Indonesia \\ 1 Faculty of Psychology, University of Airlangga
}

\begin{abstract}
Study about eco-innovation in Indonesia still very rare due to regulation that relatively new in governance of the firm. This paper elaborates the correlation between proxy of eco-innovation and financial firm performance. Eco-innovation is a term that refers to innovation activities conducted by the firm with ecological perspective based. Deductive methodology is being used to confirmatory the correlation between variables. This research examines the influence of firm financial performance towards eco-innovation. In particular, this research discusses firm financial performance which proxies by Return on Asset (ROA), Return on Equity (ROE), and Earning Retention Ratio (ERR) that could affects firms on making a decision about Eco-Innovation. This research used 155 firm years observation that consist of 31 consumer goods companies listed in Indonesian Stock Exchange during the period 2011-2015. From the total observation showed that 75 firm years perform EcoInnovation and 80 firm years did not perform Eco-Innovation. The test is conducted by using logit regression model. The results of this study are ROA has a significant and negative impact toward Eco-Innovation, ROE has a significant positive impact on Eco-Innovation, and ERR has no significant impact on Eco-Innovation.
\end{abstract}

Keywords: Financial performance, Eco-Innovation, Consumer Goods Companies 


\section{INTRODUCTION}

Innovation has been recognized as the trigger of economic and social development at national level (macro) whereas at company level (micro) innovation is the trigger of business success and competitive advantage. Supported by the statement from Michael Porter that "innovation is the central issue in economic prosperity" [8]. Nowadays, the rise of innovation activity at organizations triggered by the changes of external environment conditions both general and global (demography changes, social and culture, economic, political and law, technology, and earth climate) [5]. Consequently, innovation should obtain a new way to deal with current and future environmental problems and also reduce the use of energy and resources. This type of innovation referred to EcoInnovation / Green Innovation.

Eco-Innovationisinnovation which can reduce environment damage and develop sustainability in organization including factoreco-products, ecoprocess, and eco-organizational[7]. Urgency of the company towards EcoInnovation implementation is increasing because of the pressure from public and the changes of environment. The changes is characterized by more companies that haveISO14001. ISO14001 isinternational agreement standardwhich regulates the requirements for environmental management systems. Companies which have income derived from the higher sales often consider that this certification as "luxury good"which owned by the companies. Therefore, the company's financial performance affects a company in adopting EcoInnovation because for companies with good financial performance can allocate their investments to innovation which friendly to environment. Firm financial performance can be measured by accounting-based approaches such asReturn on Asset (ROA), Return on Equity (ROE), and Earning Retention Ratio (ERR) because that ratio is more appropriately used to measure its impact on the environment-friendly innovation activity [10].

Study conducted by Ar [1]stated that innovation on green productis positively related with firm performance and competitive advantages. Saizarbitoria et al., [12] states that company which have a better financial performance tend to implement that certificate, butthere are no evidence if that certificate affects firm financial performance. Study conducted by Lee and Min [6]states that investment in green research and developmentas proxy from Eco -Innovation have a positive and significant relationship with firm financial performance.

For the context of research conducted in Indonesia with the theme of EcoInnovation is still very rare, one of the studies carried out by Fernando, Shaharudin, and Wahid [4]in Small Medium Enterprises which engaged in the production of furniture. The results of this study found that many companies in Indonesia perform Eco-Innovation without clear guidelines and procedures regarding the rules. Another study conducted by Sueb and Keraf (2012) the result is the company has good financial performance and positively associated with the implementation of Environmental Management System.

This research is a replication of a study conducted by Przychodzen and Przychodzen [11] which examined on how the relationship between the activities of the Eco-Innovation and Financial Performance in companies in Poland and Hungary are listed on the Warsaw Stock Exchange and Budapest Stock Exchange in 2006-2013. The results from this study is the company's financial performance which are proxies 
by Return on Assets, Return on Equity and Earnings Retention Ratio positively and significantly associated with EcoInnovation. It is characterized by higher Return on Assets (ROA), and have lower Return on Equity (ROE) and Earnings Retention Ratio (ERR) in companies that adopt the Eco-Innovation

This study will analyze the influence of the company's financial performance which are proxies by ROA, ROE and ERR towards Eco-Innovation in Consumer Goods companies listed in Indonesia Stock Exchange 2011-2015 and do an interview to one of the consumer goods companies to know the constraints and barriers at the company in the implication of Eco-Innovation in the enterprise.Financial performance of the company must be follow with the perspective about sustainability of the firm. Determination to keep sustain in running a business start to get attention since the government regulation in ecological aspect of govenance. The proxy of ecological aspect of the firm usually showed by the term "eco" in many ways including innovation. Innovation that take in to account ecological aspect is known by eco-innovation. This paper will analyze the correlation between financial performance towards eco-innovation which is still marginally in literature. The results from this study are expected to contribute ideas for further research, especially for areas Eco-Innovation and is expected to give a view to taking a decision to invest in Eco-Innovation.

\section{LITERATURE REVIEW}

\subsection{Eco-Innovation}

Eco-Innovationis development of new ideas, new operational activity promotion, product and process which aim to protect the environment. EcoInnovation is related with the use of natural resource efficiently and minimize the generated waste from operational activity. Also,Eco-Innovation resulted reducing carbon emissions and waste output. Some examples of the EcoInnovation are: the use of resources of renewable energy, reuse of waste generated, the process of fertilization of water use, environmentally friendly products and some types of management [9].

\subsection{Proxy of Eco-Innovation}

Eco-Innovation can be analyzed with the following four categories:

1. Eco-Product

Eco-Product categories including environmentally friendly products that are sold into the market. This category is characterized by the use of energy efficiency, longer durability, and has the capability of easy recycle, and have a packaging line with the concept of Reuse, Reduce, Recycle [11, 13].

2. Eco-Process

Eco-Innovation in the category of eco-Process is a business process within the enterprise which is aimed at improving eco-efficiency in existing operations by introducing changes which are technological and nontechnological[11, 13]. This includes setting up an environmental report and the implementation of Environmental Management Systems [3] and also the company characterized by the accredited of ISO 140001.

3. New Markets

This category includes identifying new types of consumers who have the need for environmentally friendly products and trying to meet their needs. Innovation in this category is the transformation of the environmental laws, forcing companies to enter new markets [11].

4. Eco-sources of supply

This indicator related to selecting the contractor to reduce or replace 
components of the value chain is characterized by having a high ecological burden. It required coaching relationships with both suppliers to run hand in hand with the companies needs [11, 14].

In the study conducted by Hart (1995), Porter and van der Linde (1995), and Trung and Kumar (2005) found that the results of the company's financial performance has a positive relationship to the activities of the Eco-Innovation. Research conducted by Przychodzen and Przycodzen [11] and Artiach [2] also has the result that the Return on Asset (ROA) has a positive relationship with the activities of the Eco-Innovation. However, the research carried out by Zaho [15] and Busch and Hoffmann (2011) suggest that the Return On Asset negatively related to Eco-Innovation. Therefore, it is directed to the following hypothesis:

H_o :Return on Assets is not significantly affect Eco-Innovation in Consumer Goods Company listed on the Stock Exchange in 2011-2015

$\mathrm{H} \_1$ :Return on Assets is significantly affect (positive / negative) EcoInnovation in Consumer Goods Company listed on the Stock Exchange 2011-2015

In the study conducted by Przychodzen and Przycodzen [11] and Artiach [2] also has the result that the Return on Equity (ROE) has a positive relationship with the activities of the Eco-Innovation.

Therefore, it is directed to the following hypothesis:

H_o :Return on Equity is not significantly affect Eco-Innovation in Consumer Goods Company listed on the Stock Exchange in 2011-2015

$\mathrm{H} \_2$ : Return on Equity is significantly affect (positive / negative) EcoInnovation in Consumer Goods
Company listed on the Stock Exchange 2011-2015

Research conducted by Przychodzen and Przycodzen [11] have the results of a significant and negative relationship exists between Earning Retention Ratio (ERR) with Eco-Innovation activities. Therefore, it is directed to the following hypothesis

H_o : Earning Retention Ratio is not significantly affect Eco-Innovation in Consumer Goods Company listed on the Stock Exchange in 2011-

H_3 : Earning Retention Ratiois significantly affect (positive / negative) Eco-Innovation in Consumer Goods Company listed on the Stock Exchange 2011-2015

\section{RESEARCH METHODOLOGY}

This research is an explanatory research that aims to explain the influence of the independent variable on the dependent variable. The independent variable in this study are ROA, ROE, ERR, and the dependent variable isEcoInnovationwhich categorized by dummy variable ( 1 if companies perform EcoInnovation, and $\mathrm{o}$ if companies didn't perform Eco-Innovation).

In addition this study using control variables, that are leverage, financial capacity and firm size. This study also analyze the obstacles and barriers in one of the consumer goods companies whose perform Eco-Innovation. This study is using 31 consumer goods companies listed on the Stock Exchange period 20112015 with total observationsas much as 155 observations and divided into 75 firm years whoperform Eco-Innovationand 80 firm years who didn't perform EcoInnovation.

The hypothesis is test using Logit Regression because the dependent of this research is dummy variable which adapted from a equation 1 below : 


$$
\begin{aligned}
& \text { ECOINNOV }_{\text {it }} \\
&= \alpha+\beta \mathrm{ROA}_{i t}+\gamma \mathrm{ROE}_{\mathrm{it}}+\theta \mathrm{ERR}_{\mathrm{it}}+\mu \mathrm{LVR}_{\mathrm{it}}+ \\
& \rho \mathrm{FINCAP}_{\mathrm{it}}+\ln \mathrm{TA}_{\mathrm{it}}+\varepsilon_{\mathrm{it}}
\end{aligned}
$$

(This equation is adopted from Przychodzen and Przychodzen [11], and Artiach et al., [2] ).

Where :

- ECOINNOV is a dummy variable : the value of ECOINNOV is 1 if companies perform EcoInnovation, and $\mathrm{o}$ if the company didn't perform Eco-Innovation) [2] and [11].

- ROA is Return on Assets measured by EBIT / total assets [2] and [11].

- ROE: Return on Equity, measured by net income / total equity[2] and [11].

- ERR: Earning Retention Ratio measured by net income-dividend / net income[2] and [11].
- Leverage (LEV) measured by total debt / total assets[2] and [11].

- Financial Capacity (FINCAP) is measured by free cash flow / net sales [2] and [11].

- Firm Size is (SIZE) measured by Natural logarithm of total assets[2] and [11].

\section{RESULTS AND DISCUSSION 4.1 Descriptive Analysis}

Table 1 shows that the results of descriptive statistics on companies who perform Eco-Innovation and didn't perform Eco-Innovation. From the results below Consumer Goods companies that perform Eco-Innovation tend to be larger than a company that did not perform Eco-Innovation. As for other variables such as ROA, ROE, ERR, LEV, FINCAP for companies that didn't perform Eco-Innovation have a larger value than a company that does the EcoInnovation.

\begin{tabular}{llccccc}
\multicolumn{7}{c}{ Table 1. Descriptive Statistic } \\
\hline \multirow{2}{*}{ Variable } & $\begin{array}{c}\text { Eco- } \\
\text { Innovatio }\end{array}$ & N & Mean & $\begin{array}{c}\text { Mini- } \\
\text { mum }\end{array}$ & $\begin{array}{c}\text { Maxi- } \\
\text { mum }\end{array}$ & $\begin{array}{c}\text { Std. } \\
\text { Deviation }\end{array}$ \\
\hline \multirow{2}{*}{ ROA(\%) } & No & 80 & 17,665 & $-17,030$ & 88,485 & 18,607 \\
& Yes & 75 & 13,890 & $-4,869$ & 53,957 & 13,380 \\
\multirow{2}{*}{ ROE(\%) } & No & 80 & 20,637 & $-163,132$ & 143,533 & 40,285 \\
& Yes & 75 & 20,120 & $-9,177$ & 125,805 & 28,879 \\
\multirow{2}{*}{ ERR(\%) } & No & 80 & 66,831 & $-71,830$ & 100,000 & 43,344 \\
& Yes & 75 & 65,571 & $-72,520$ & 100,000 & 37,265 \\
\multirow{2}{*}{ LEVERAGE(\%) } & No & 80 & 22,336 & 0,000 & 75,177 & 19,719 \\
& Yes & 75 & 13,294 & 0,000 & 47,047 & 13,506 \\
\multirow{2}{*}{ FINCAP(\%) } & No & 80 & 7,460 & $-21,448$ & 47,537 & 14,855 \\
& Yes & 75 & 6,297 & $-14,057$ & 40,808 & 10,548 \\
SIZE & No & 80 & 9,208 & 6,925 & 10,802 & 0,809 \\
& Yes & 75 & 9,379 & $8,624,158$ & 10,953 & 0,635 \\
\hline
\end{tabular}

\subsection{Pearson Correlation Test}

In the Pearson correlation test below shows the correlation results of each independent variable in this study. There are no significant correlation found between LEV with ROA, ROE with LEV, ROE with SIZE, FINCAP with LEV, LEV with SIZE, and FINCAP with SIZE. This indicates that there is no relationship between these variables. While other variables that have a significance value below 0.01 and 0.05 means that there is a correlation in these variables. 
Table 2. Pearson Correlation Test

\begin{tabular}{|c|c|c|c|c|c|c|}
\hline Variable & ROA & ROE & ERR & $\begin{array}{c}\text { LEVER } \\
\text { AGE }\end{array}$ & FINCAP & SIZE \\
\hline ROA & $\begin{array}{l}1,0 \\
(0,000)\end{array}$ & & & & & \\
\hline ROE & $\begin{array}{l}0,840 * * \\
(0,000)\end{array}$ & $\begin{array}{l}1,0 \\
(0,000)\end{array}$ & & & & \\
\hline ERR & $\begin{array}{l}-0,629^{* *} \\
(0,000)\end{array}$ & $\begin{array}{l}-0,544^{* *} \\
(0,000)\end{array}$ & $\begin{array}{l}1,0 \\
(0,000)\end{array}$ & & & \\
\hline LEVERAGE & $\begin{array}{l}-0,152 \\
(0,060)\end{array}$ & $\begin{array}{l}0,036 \\
(0,660)\end{array}$ & $\begin{array}{l}0,244^{* *} \\
(0,002)\end{array}$ & $\begin{array}{l}1,0 \\
(0,000)\end{array}$ & & \\
\hline FINCAP & $\begin{array}{l}0,495^{* *} \\
(0,000)\end{array}$ & $\begin{array}{l}0,429 * * \\
(0,000)\end{array}$ & $\begin{array}{l}-0,337^{* *} \\
(0,000)\end{array}$ & $\begin{array}{l}-0,026 \\
(0,752)\end{array}$ & $\begin{array}{l}1,0 \\
(0,000)\end{array}$ & \\
\hline SIZE & $\begin{array}{l}0,200 * * \\
(0,013)\end{array}$ & $\begin{array}{l}0,151 \\
(0,061)\end{array}$ & $\begin{array}{l}-0,210 * * \\
(0,009)\end{array}$ & $\begin{array}{l}0,057 \\
(0,484)\end{array}$ & $\begin{array}{l}-0,140 \\
(0,083)\end{array}$ & $\begin{array}{l}1,0 \\
(0,000)\end{array}$ \\
\hline
\end{tabular}

Table 3 shows that the results of Hosmer and Lemeshow test is intended to test the suitability or appropriateness in predictive logistic regression model to the observed data. The result of Chi Square is 7.273 with a significance level of 0.507. The significance level of 0.507 is greater than the value of $\alpha$ which is 0.05 , this can be concluded that the model predicted are suitable or appropriate, so the model can predict the observed values.

Table 3. Hosmer and Lemeshow Test

\begin{tabular}{|l|r|r|c|}
\hline Step & Chi-square & \multicolumn{1}{c|}{ df } & Sig. \\
\hline 1 & 7,273 & 8 &, 507 \\
\hline
\end{tabular}

The next step in Logistic regression is the regression coefficient testing overall (overall model) with Omnibus Test of Model Coefficient. The test give the results of the Chi Square goodness of fit is 41.551 with degrees of freedom $(\mathrm{df})=6$. The probability are 0,000 is smaller than the value of $\alpha=5 \%$ so the test is significant and reject Ho, which means at least one independent variable significantly influence Eco-Innovation.
Coefficient

\begin{tabular}{|rl|r|r|r|}
\hline & & Chi-square & df & \multicolumn{1}{c|}{ Sig. } \\
\hline Step 1 & Step & 41,551 & 6 &, 000 \\
& Block & 41,551 & 6 &, 000 \\
& Model & 41,551 & 6 &, 000 \\
\hline
\end{tabular}

Classification matrix in Table 5 shows the strength of predicting chances predictions in the regression model from the company in performing the Eco-Innovation. The results are from 155 firm year that didn't perform EcoInnovation , as many as 58 companies, or $72.5 \%$ accurately can be predicted by a logistic regression model, and as many as 22 companies of samples can not be predicted by the model. While the 155 firm years whose perform EcoInnovation, as many as 58 companies, or $77.3 \%$ appropriately predicted by logistic regression model, and as many as 17 other companies can not be estimated from the observation. Overall, this classification test results show the percentage of $74.8 \%$ of the sample can be predicted exactly by this logistic regression model.

Table 4. Omnibus Test of Model 
Table 5. Classification Table

\begin{tabular}{|c|c|c|c|c|c|}
\hline & & & \multicolumn{3}{|c|}{ Predicted } \\
\hline & & & Eco & & \\
\hline \multicolumn{3}{|c|}{ Observed } & Tidak & Ya & Correct \\
\hline \multirow[t]{3}{*}{ Step 1} & \multirow[t]{2}{*}{ Ecolnnov } & Tidak & 58 & 22 & 72,5 \\
\hline & & Ya & 17 & 58 & 77,3 \\
\hline & \multicolumn{2}{|c|}{ Overall Percentage } & & & 74,8 \\
\hline
\end{tabular}

In table 6 the value of Cox and Snell's $\mathrm{R}$ Square amounted to 0.238 this means that the variables contained in logit model is able to explain a company perform Eco-Innovation or not is of $23.8 \%$. While based on the value of Nagelkerke R Square is 0.317 which shows that $31.7 \%$ of variation of the dependent variable which is Eco-Innovation can be explained by the variability of independent variables there are ROA, ROE, ERR, LEV, FINCAP, and Log SIZE. While 68.3\% can be explained by other variables outside the model.

Table 6. Cox and Snell's R Square and Nagelkerke R Square Results

\begin{tabular}{|l|c|c|c|}
\hline \multicolumn{4}{|c|}{ Model Summary } \\
\hline Step & $\begin{array}{c}-2 \text { Log } \\
\text { likelihood }\end{array}$ & $\begin{array}{c}\text { Cox \& Snell R } \\
\text { Square }\end{array}$ & $\begin{array}{c}\text { Nagelkerke R } \\
\text { Square }\end{array}$ \\
\hline 1 & $172,679^{\text {a }}$ &, 238 &, 317 \\
\hline
\end{tabular}

Table 7. Logistic Regression ResultsVariables in the Equation

\begin{tabular}{llcccccc}
\hline & B & S.E. & Wald & df & Sig. & Exp(B) \\
\hline ROA & $-0,167$ & 0,042 & 16,068 & 1 & $\mathbf{o , o o 0}^{*}$ & 0,846 \\
ROE & 0,059 & 0,019 & 9,578 & 1 & $\mathbf{o , o o 2}^{*}$ & 1,061 \\
ERR & 0,00025 & 0,006 & 0,002 & 1 & 0,969 & 1,000 \\
Step 1 & LEVERAGE & $-0,074$ & 0,016 & 21,032 & 1 & $\mathbf{o , o o 0}^{*}$ & 0,929 \\
& FINCAP & 0,030 & 0,018 & 2,829 & 1 & $\mathbf{o , o 9 3}^{*}$ & 1,031 \\
& SIZE & 0,899 & 0,301 & 8,888 & 1 & $\mathbf{o , o o 3}^{*}$ & 2,456 \\
& Constant & $-6,019$ & 2,776 & 4,702 & 1 & $\mathbf{o , o 3}^{*}$ & 0,002 \\
\hline
\end{tabular}

*Significant on level 5\%, ** Significant on level 10\%

Table 7 shows the results of Logistic Regression, the value of coefficient logistic regression for variable ROA is $-0,167$ and significant value for ROA is 0,000 it means that this value sis smaller than level of significance which is $5 \%(0,05)$ so it can be concluded that the results of this research is rejected Ho. So, that Return on Assethave a significant and negatively impact on EcoInnovation. Relationship between ROA and Eco-Innovation can be interpreted by seeing the value of odds ratio( $\operatorname{Exp}(B))$. Value 0,846 means that if ROA increase by $1 \%$ with assumption another factor stable so it will be gain the opportunity of the companies for not perform EcoInnovation as much as 0,846 . The results is in accorandce with study conducted by Zaho [15], the possible reason for this result is companies who has higher ROA cannot guarantee the revenue will be used to invest in Eco-Innovation.

For variable ROE the coefficient is 0,059 and significant value for $\mathrm{ROE}$ is 0,002 it means that this value is smaller than level of significance which is 5\% $(0,05)$ so it can be concluded that the results of this research is rejected Ho. So that Return on Equityhave a significant and positive impact on Eco-Innovation. Relationship between ROE and EcoInnovation can be interpreted by seeing the value of odds ratio( $\operatorname{Exp}(B))$. Value 1,046 means that if ROA increase by $1 \%$ with assumption another factor stable so it will be gain the opportunity of the companies for perform EcoInnovation as much as 1,046. The results are in accorandce with study conducted by Artiach et al., [2], Hart and Ahuja (1996). The possible reason for this result is the amount of roe in the companies means that the company's equity in demand by many investors and also if stakeholders in companies have a good comprehension about what is the advantages for firm to adopt Eco-Innovation it will affect the decision making in the firm to invest.

For variable ERR the coefficient is 0,00025 and significant value for ROE is 0,969 it means that this value is bigger than level of significance which is $5 \%$ 


\section{Diah Permata Sari1; Retno Kusumastuti ${ }^{2}$}

$(0,05)$ so it can be concluded that the results of this research is approved Ho. So that Earning Retentio Ratio didn'thave a significant impact on Eco-Innovation. Relationship between ERRand EcoInnovation can be interpreted by seeing the value of odds ratio(Exp(B)). So that if ERR happen to increase or decrease it will not affect firm in make a decision to invest in Eco-Innovation.

For control variable in this research, firstly leverage it has a significant and negatively affect towards EcoInnovation. It means that firm who has a large leverage in the companies tend to not invest in Eco-Innovation because they have a responsibility to pay the debt to debtholders. For financial capacity have a significant and positive impact towards Eco-Innovation, it means that the greater the financial capacity of the companies it will impact the companies to make a decision to invest in EcoInnovation. Same with variable Size, it has a significant and positive impact towards Eco-Innovation. Same with the results from descriptive statistics it shows that firm who perform Eco-Innovation tend to be larger than firm who didn't perform Eco-Innovation.

Analysis for constraints and barriers in one of the Consumer Goods Companies, researcher doing an interview with informant from one company and the results is they face some constraints if the process of Eco-Innovation implementation didn't goes well, it means that aims of the firms is to make a chances towards more environmentally friendly and sustainable nature so if the goal has not been achieved maybe it has a problems. The problems may come from every line of production or also when it used by the customers, the comprehension about Eco-Innovation in every person is different. The companies task to make the goal achieved are communicate it to the public, whether it would be through online media, advertising in television, etc.

\section{CONCLUSION}

Conclusion of this research are firm financial performance which is proxies by Return on Asset, Return on Equity, and Earning Retention Ratio has variant results in his influence towards Eco-Innovation. For variable return on asset have significant and negative impact towards Eco-Innovation, while variable return on equity have significant and positive impact towards Eco-Innovation. The last independent variable which is earning retention ratio have not significant impact towards EcoInnovation it means that ERR didn't influence companies to make a decision to invest in Eco-Innovation. For constraints and barriers one of the consumer goods companies, the informant stated that the companies faced constraints if the Eco-Innovation implementation didn't goes well, and the idea of change do not walk on each product line. To manage consumer comprehension about EcoInnovation, the companies should be more cooperative to communicate to public whether it would be through social media, advertising, and television advertising.

This research has limitation related to explain the cause of firm financial performance indicator of the company in order to make a decision in performing Eco-Innovation, so future research is expected to use another proxies of firm financial performance such as Return on Investment and return on Sales as well as the research conducted by Hart and Ahuja, (1996). Also on this research, the Eco-Innovation indicator presented above are based on content analysis on firm annual report, which may present some threat to its validity and reliability. Thus the results obtained may not be easily replicable. For future research 
conducted in Indonesia, is expected to use another Eco-Innovation indicator such as a company which is publish PROPER results done by The State Ministry of the Environment. In addition, further research is expected to have broader scope and applied to different sectors. In this research, interview was done by researcher to analyze what are the constraints and barriers of consumer goods companies, but it has limitation because the researcher only interview one of the consumer goods company so that it cannot be generalized to another companies in this research, for further research is expected to interview more companies.

\section{REFERENCES}

[1] Ar, Ilker, Murat. (2012),"The impact of green product innovation on firm performance and competitive capability: the moderating role of managerial environmental concern", Procedia-Social and Behavioral Sciences, Volume 62, pp. 854-864.

[2] Artiach, Tracy., Lee, Darren., Nelson, David., Walker, Julie. (2010)., "The determinants of corporate sustainability performance",Journal of Accounting and Finance, Volume50,pp. 31-51.

[3] Demiral, P., Kesidou, E., (2011), "Stimulating different types of ecoinnovation in the UK: government policies and firm motivations", Journal of Ecological Economics, Volume 70, 1546-1557.

[4] Fernando, Yuri., Shaharudin, Muhammad Shabir., Wahid, Nabsiah Abdul. (2016), "EcoInnovation practice: a case study of green furniture manufacturers in Indonesia.”, Journal of Services and Operations Management, Volume 23, No. 1.

[5] Fontana, Avanti. (2011). Innovate
We Can! How to Create Value through Innovation in Your Organization and Society. Jakarta: Cipta Inovasi Sejahtera.

[6] Lee, Ki-Hoon., Min, Byung. (2015)," Green R\&D for eco-innovation and its impact on carbon emissions and firm performance", Journal of Cleaner Production.

[7] Nimet, Erygit., Ozcure, Gurol. (2015), "Eco-Innovation as Modern Era Strategy of Companies in Developing Countries: Comparison Between Turkey And European Union", Procedia - Social and Behavioral Sciences, Volume195, $1216-1225$.

[8] OECD, 2009. Sustainable Manufacturing and Eco-Innovation, Framework, Practies and Measurement. Synthesis Report. http//www.oecd.org/.pdf

[9] Panapanaan, V.,Uotila, T. \& Jalkala, A. (2014). Creation and Alignment of the Ecoinnovation Strategy Model to Regional Innovation Strategy: A Case from Lahti (Päijät-Häme Region).

[10] Peloza, J. (2009), "The challenge of measuring financial impacts from ivesments in corporate social performance”, Journal Managements, Volume35 (6), 15181541.

[11] Przychodzen,Justyna.,Przychodzen, Wojciech. (2014), "Relationship between eco-innovation and financial performace - evidence from publicly traded companies in Poland and Hungary", Journal of Cleaner Production.

[12] Saizarbitoria, Inaki, Heras., Azorin J, F, M., Dick, Gavin, P, M. (2010). ISO 14001 certification and financial performance: selection

[13] Ziegler, Andreas., Rennings, Klaus. (2004). Determinants of Environmental Innovations in 
Germany: Do Organizational Measures Matter? A Discrete Choice Analysis at the Firm Level. Centre for European Economic Research.

[14] Rogers, M. (1998). The Definition and Measurement of Innovation. Melbourne Institute of Applied Economic and Social Research. University of Mellbourne. Working Paper no. 10798. https:// www.melbourneinstitute.com/ downloads/workinng_paper series/wp1998n10.pdf17/09/2016 jam 20.00

[15] Zaho, J., (2008), "The Effect on corporate financial performance",International Journal of Business Excellence, 1, 210-230. 